\title{
Spatial distribution of organic carbon and humic substances in irrigated soils under different management systems in a semi-arid zone in Ceará, Brazil
}

\author{
Distribuição espacial do carbono orgânico e substâncias húmicas \\ sob diferentes manejos com irrigação em clima semiárido no Ceará, \\ Brasil
}

\author{
Antônia Arleudina Barros de Melo하 Gustavo Souza Valladares²; \\ Marcos Bacis Ceddia ${ }^{3}$; Marcos Gervasio Pereira ${ }^{4 *}$;smail Soares ${ }^{5}$
}

\begin{abstract}
Knowledge of the spatial variability in soil properties can contribute to effective use and management. This study was conducted to evaluate the spatial distribution of the levels of total organic carbon (TOC) and humic substances (humic acid (C-FAH), fulvic acid fraction (C-FAF), and humin fraction $(\mathrm{C}-\mathrm{HUM}))$ in an Ultisol under different land uses, located in the irrigated perimeter of Baixo Acaraú$\mathrm{CE}$, transition to semiarid Ceará. The distribution and spatial dependence of the humic fractions were evaluated using descriptive statistics, including semivariogram analysis and data interpolation (kriging). The TOC showed a pure nugget effect, whereas the other fractions showed moderate spatial dependence. Forested and banana cultivation areas showed similar distributions of C-FAH and C-FAF, due to the high input of organic matter (leaves and pseudostems) in the area of banana cultivation and the absence of soil disturbance in the forested area. Data interpolation (kriging) and mapping were useful tools to assess the distribution and spatial dependence of soil attributes.
\end{abstract}

Key words: Variability. Soil organic matter. Kriging.

\section{Resumo}

O conhecimento da variabilidade espacial de atributos do solo pode contribuir para racionalizar seu uso e manejo. Este estudo foi realizado com o objetivo de avaliar a distribuição espacial dos teores de carbono orgânico total (COT) e das substâncias húmicas (fração ácido húmico (C-FAH), fração ácido fúlvico (C-FAF) e fração humina (C-HUM)) em um Argissolo Amarelo sob diferentes usos, localizado no perímetro irrigado do Baixo Acaraú-CE, transição para o semiárido do Ceará. As amostras simples foram coletadas em grade irregular com 100 pontos, na profundidade de 0,0 a 0,20 m. Foi avaliada a distribuição e a dependência espacial das frações húmicas por meio de estatística descritiva, semivariogramas e interpolação de dados (krigagem). Com exceção do COT, que apresentou efeito pepita puro, para as demais frações foi observada dependência espacial moderada. As áreas da

\footnotetext{
${ }^{1}$ M.e em Agronomia, Solos e Nutrição de Plantas, Programa de Pós-Graduação em Solos e Nutrição de Plantas, Universidade Federal do Ceará, UFC, Fortaleza, CE, Brasil. E-mail: arleudinamelo@yahoo.com.br

2 Prof. Dr. em Agronomia, Ciência do Solo, Universidade Federal do Piauí, UFPI, Teresina, PI, Brasil. E-mail: valladares@ufpi. edu.br

3 Prof. Dr. em Agronomia, Ciência do Solo, Universidade Federal Rural do Rio de Janeiro, UFRRJ, Seropédica, RJ. Brasil. E-mail: marcosceddia@gmail.com

4 Prof. Dr., Agronomia Ciência do Solo, UFRRJ, Seropédica, RJ. Brasil. E-mail: mgervasiopereira01@gmail.com

5 Prof. Dr. em Agronomia, Solos e Nutrição de Plantas, UFC, Fortaleza, CE, Brasil. E-mail: soaresufc@hotmail.com

* Author for correspondence
} 
cultura de banana e de mata apresentaram distribuição semelhante das frações húmicas, $\mathrm{C}$ - FAH e $\mathrm{C}-\mathrm{FAF}$, devido ao maior aporte de matéria orgânica (folhas e pseudocaule) na área de banana e ao não revolvimento do solo na área de mata. A interpolação dos dados (krigagem) e confecção de mapas foram ferramentas úteis para avaliar a distribuição e dependência espacial dos atributos do solo.

Palavras-chave: Variabilidade. Matéria orgânica do solo. Krigagem

\section{Introduction}

In agricultural systems, the dynamics of soil organic matter (SOM) can be influenced by soil management and preparation, culture selection, and addition of fertilizers and organic materials that affect the processes of decomposition and mineralization (LEITE et al., 2003). Overall, humic substances represent approximately $70 \%$ of the total soil organic carbon (TOC) that influences the physical and chemical properties of the soil, and consequently fertility, contributing to increased crop yields (CUNHA et al., 2009; MADARI et al., 2009).

In addition to quantity, the quality of the organic matter is important, because $\mathrm{C}$ is a source of nutrients and energy for microorganisms, and affects soil functions such as water retention, aggregate stability, and availability of micro and macronutrients, among others (MADARI et al., 2009). Organic matter quality can be evaluated by quantification of carbon levels associated with various humic substances. These can be distinguished based on chemical characteristics such as solubility, density, and molar mass, as they have different physicochemical characteristics (CUNHA et al., 2005).

In recent decades, many studies have been conducted on humic substances in Brazil (LEITE et al., 2003; LOSS et al., 2006; EBELING et al., 2011; VALLADARES et al., 2011). However, only a few studies have been conducted on humic substances in northeastern Brazil, mainly by Cunha et al. (2009) and Souza et al. (2012).

The effects of management systems that promote different plant biomass contributions can be assessed through characterization of humic substances. Analysis of their effect on soil properties can assist in evaluation of soil quality (CUNHA et al., 2005; MARTINS et al., 2009; LOSS et al., 2010), as changes in land use can alter the content and quality of SOM (PESSOA et al., 2012).

Geostatistical techniques provide information on the spatial variability of soil properties in a sampled area, and this knowledge enables planning of appropriate management for each area, by providing detailed data on the effects of soil management that can be used to inform adjustment of inputs and other farming techniques. Thus, geostatistical techniques can be used to determine the minimum number of replicates required for characterization of soil physical and chemical attributes (SOUZA et al., 2006), and to understand how these attributes vary with crop production response, enabling rational, localized, and individualized application of inputs (LIMA et al., 2010).

Given that spatial variability in soil properties, vegetation cover, and management influence organic carbon content and SOM composition, this study aimed to assess and map the spatial variability of total organic carbon (TOC) and humic substances (humic acid fraction (C-HAF), fulvic acid fraction (C-FAF), and humin (C-HUM)) in a Ultisol under different management, at 0-20 cm, using descriptive statistics and geostatistical techniques.

\section{Materials and Methods}

The study area is located in the irrigated perimeter of Baixo Acaraú-CE (Figure 1), occupies approximately $0.75 \mathrm{ha}$, and is located at $40^{\circ} 3^{\prime}$ $48.8^{\prime \prime} \mathrm{W}$, and $3^{\circ} 6^{\prime} 29.1^{\prime \prime} \mathrm{S}$, between the metric coordinates 9656400 and 9656520 south latitude and 381820 and 381940 west longitude (UTM 
Datum Córrego Alegre, Zone 24). The area is divided into three distinct uses: native forest $(0.13$ ha), guava cultivation (Psidium guajava L., 0.42 ha), and banana cultivation (Musa cavendishii, 0.20 ha). The forest area consists of "capoeira" (secondary forest) made up of shrubby "caatinga" (desert-like vegetation), that has been regenerating for over ten years. Guava cultivation began four years ago, and in the first two years guava was planted in combination with passion fruit (Passiflora edulis). The area is irrigated by microaspersion, with $6 \mathrm{~m}$ $\times 6 \mathrm{~m}$ spacing between plants. Between the rows of plants the soil is bare, favoring erosion and exposure to sunlight. The banana cultivation area has been irrigated by microaspersion for six years; for the first two years, it was under papaya (Carica papaya) cultivation, and bananas have been grown for the remaining four. Spacing between plants is 2 $\mathrm{m}$, with $2.0 \mathrm{~m}$ and $4.0 \mathrm{~m}$ between single and double rows, respectively. The soil is completely covered by crop residues (leaves and stalks), and the soil beneath the banana plants is shaded.

Figure 1. Map of Acaraú county in the state of Ceará, highlighting the study area and the scheme for spatial variability sampling.

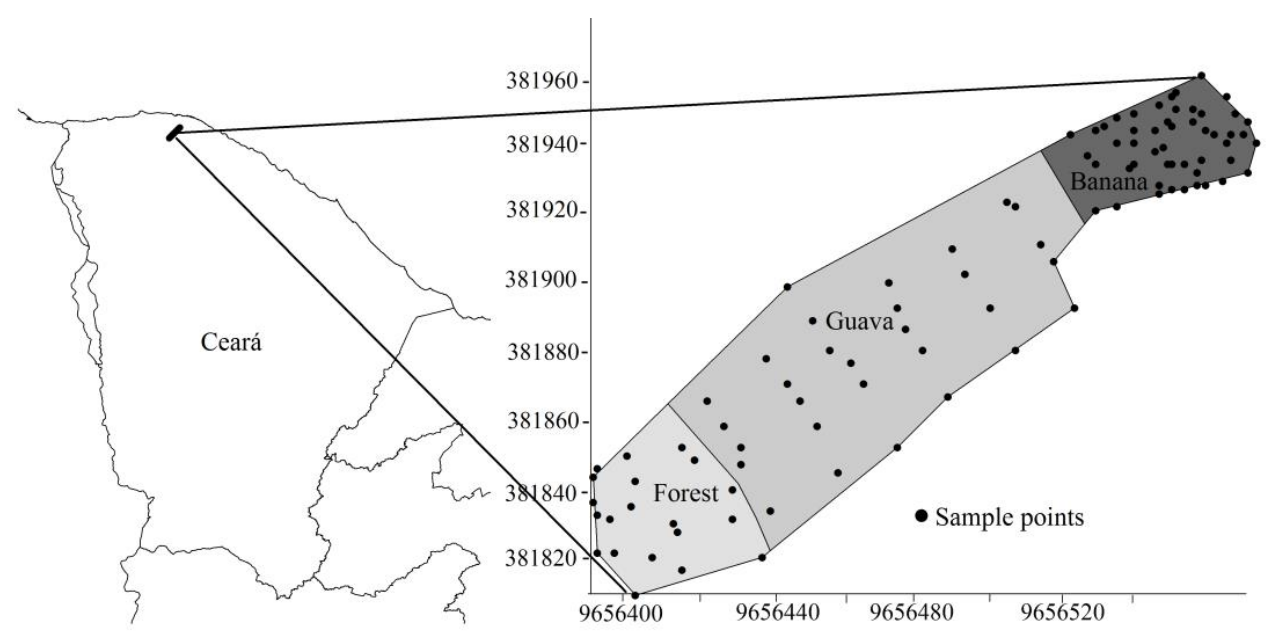

The irrigated perimeter of Baixo Acaraú is located in northern Ceará State, at the edge of the Rio Acaraú basin, encompassing areas in the municipalities of Acaraú, Bela Cruz, and Marco, $220 \mathrm{~km}$ from Fortaleza.

The average annual rainfall is $900 \mathrm{~mm}$, with an average annual temperature of $28.1^{\circ} \mathrm{C}$, an average of 2,650 h of sun per year, annual mean relative humidity of $70 \%$, and mean annual evaporation of 1,600 mm (SUDEC/Departamento Nacional de Obras Contra a Seca, 1974). The study area is flat at the collection points, typical of the Tabuleiros Costeiros, with a predominance of deep and well- drained Ultisols, which were formed from the Barreiras Group sediments. The water supply for the irrigated area is the Acaraú River, which is made perennial in the area by water from the Paulo Sarasate and Edson Queiroz public dams. The main irrigation systems are microaspersion and drip.

To classify the study area soils we opened two trenches, one in an area of native vegetation and another in an area under banana cultivation. Both soil samples were classified as Ultisols with character dystrophic and abruptic. The results of physical and chemical analyses can be found in Tables 1 and 2 . 
Table 1. Granulometry and textural classification of soil profiles collected in the forested and banana cultivation areas.

\begin{tabular}{|c|c|c|c|c|c|c|}
\hline \multicolumn{7}{|c|}{ Profile 1 Forested area } \\
\hline Horizon & Depth & $\begin{array}{c}\text { Coarse } \\
\text { sand }\end{array}$ & $\begin{array}{l}\text { Fine } \\
\text { sand }\end{array}$ & Silt & Clay & Textural Class \\
\hline \multicolumn{7}{|c|}{$\mathrm{g} \mathrm{kg}^{-1}$} \\
\hline A1 & $0-10$ & 681 & 221 & 49 & 49 & Sand \\
\hline $\mathrm{A} 2$ & $10-20$ & 516 & 406 & 29 & 49 & Sand \\
\hline $\mathrm{AB}$ & $20-55$ & 605 & 280 & 33 & 82 & Sand \\
\hline Bt1 & $55-80$ & 525 & 234 & 42 & 198 & Sandy-Loam \\
\hline $\mathrm{Bt} 2$ & $80-120$ & 502 & 250 & 41 & 208 & Sandy-Clay-Loam \\
\hline Bt3 & $120-150$ & 546 & 221 & 42 & 191 & Sandy-Loam \\
\hline \multicolumn{7}{|c|}{ Profile 2 Banana cultivation area } \\
\hline Horizon & Depth & $\begin{array}{c}\text { Coarse } \\
\text { sand }\end{array}$ & $\begin{array}{l}\text { Fine } \\
\text { sand }\end{array}$ & Silt & Clay & Textural Class \\
\hline \multicolumn{7}{|c|}{$\mathrm{g} \mathrm{kg}^{-1}$} \\
\hline Ap1 & $0-12$ & 691 & 194 & 60 & 55 & Sand \\
\hline Ap2 & $12-20$ & 663 & 234 & 36 & 67 & Sand \\
\hline $\mathrm{Bt} 1$ & $20-50$ & 615 & 190 & 48 & 147 & Sandy-Loam \\
\hline $\mathrm{Bt} 2$ & $50-80$ & 434 & 392 & 41 & 133 & Sandy-Loam \\
\hline $\mathrm{Bt} 3$ & $80-130+$ & 509 & 227 & 49 & 215 & Sandy-Clay-Loam \\
\hline
\end{tabular}

Table 2. Chemical characterization of soil profiles.

\begin{tabular}{|c|c|c|c|c|c|c|c|c|c|c|c|c|c|c|}
\hline \multicolumn{15}{|c|}{ Pofile 1 Forested area } \\
\hline Hor & Prof. & $\begin{array}{c}\mathrm{pH} \\
\mathrm{H}_{2} \mathrm{O}\end{array}$ & pHKCI & $\mathrm{Ca}^{2+}$ & $\mathbf{M g}^{2+}$ & $\mathbf{N a}^{+}$ & $\mathbf{K}^{+}$ & SB & $\mathbf{A l}^{3+}$ & $\begin{array}{l}\mathbf{H}^{+}+ \\
\mathbf{A l}^{3+}\end{array}$ & CEC & $\mathbf{V}$ & PST & $\mathbf{P}$ \\
\hline & $\mathrm{cm}$ & & & \multicolumn{8}{|c|}{ cmolc kg-1 $^{-1}$} & \multicolumn{2}{|c|}{$\%$} & $\mathrm{mg} \mathrm{kg}^{-1}$ \\
\hline A1 & $0-10$ & 6.1 & 5.0 & 0.6 & 1.0 & 0.02 & 0.19 & 1.8 & 0.00 & 1.73 & 3.55 & 51 & 1 & 2.9 \\
\hline A2 & $10-20$ & 5.4 & 5.1 & 0.3 & 0.1 & 0.01 & 0.07 & 0.5 & 0.00 & 0.49 & 0.97 & 50 & 1 & 0.3 \\
\hline $\mathrm{AB}$ & $20-55$ & 5.2 & 4.0 & 0.2 & 0.2 & 0.02 & 0.06 & 0.5 & 0.25 & 0.83 & 1.31 & 37 & 1 & 0.1 \\
\hline Bt1 & $55-80$ & 5.2 & 4.1 & 0.2 & 0.3 & 0.02 & 0.02 & 0.5 & 0.00 & 1.98 & 2.53 & 22 & 1 & 0 \\
\hline Bt2 & $80-120$ & 5.1 & 4.0 & 0.2 & 0.1 & 0.02 & 0.03 & 0.4 & 0.10 & 1.98 & 2.33 & 15 & 1 & 0 \\
\hline Bt3 & $120-150$ & 5.2 & 4.0 & 0.2 & 0.2 & 0.02 & 0.03 & 0.5 & 0.50 & 2.31 & 2.77 & 17 & 1 & 0 \\
\hline \multicolumn{15}{|c|}{ Profile 2 Banana cultivation area } \\
\hline \multirow[t]{2}{*}{ Hor } & Prof. & $\begin{array}{c}\mathrm{Ph} \\
\mathrm{H}_{2} \mathrm{O}\end{array}$ & PhKCl & $\mathrm{Ca}^{2+}$ & $\mathbf{M g}^{2+}$ & $\mathbf{N a}^{+}$ & $\mathbf{K}^{+}$ & SB & $\mathbf{A l}^{3+}$ & $\begin{array}{c}\mathbf{H}^{+}+ \\
\mathbf{A l}^{3+}\end{array}$ & CEC & $\mathbf{V}$ & PST & $\mathbf{P}$ \\
\hline & $\mathrm{cm}$ & & & & & & $\mathrm{cmol}$ & $\mathrm{kg}^{-1}$ & & & & \multicolumn{2}{|c|}{$\%$} & $\mathrm{mg} \mathrm{kg}^{-1}$ \\
\hline Ap1 & $0-12$ & 6.7 & 5.8 & 1.6 & 1.2 & 0.23 & 0.07 & 3.1 & 0.05 & 1.65 & 4.76 & 65 & 5 & 4.8 \\
\hline Ap2 & $12-20$ & 6.3 & 5.1 & 0.3 & 0.6 & 0.06 & 0.05 & 1.0 & 0.00 & 1.49 & 2.50 & 41 & 3 & 0.5 \\
\hline Bt1 & $20-50$ & 6.2 & 4.6 & 0.3 & 0.6 & 0.06 & 0.13 & 1.1 & 0.20 & 2.31 & 3.41 & 32 & 3 & 2.1 \\
\hline $\mathrm{Bt} 2$ & $50-80$ & 5.9 & 4.3 & 0.3 & 0.4 & 0.06 & 0.04 & 0.8 & 0.20 & 1.65 & 2.45 & 33 & 2 & 1.0 \\
\hline $\mathrm{Bt} 3$ & $80-130+$ & 4.9 & 3.8 & 0.2 & 0.4 & 0.04 & 0.02 & 0.7 & 0.00 & 2.48 & 3.14 & 21 & 1 & 0 \\
\hline
\end{tabular}

PST $=$ Percentage of saturation by sodium $(100 \mathrm{Na} / \mathrm{T}) ; \mathrm{SB}=\mathrm{Sum}$ of bases; $\mathrm{CEC}=$ cation exchange capacity.

Samples were collected with an auger in an was collected at each point at a depth of 0.0-0.20 irregular grid containing 100 points, covering a m, from forested (20 points, collected at random), continuous area with different uses. A single sample guava cultivation (30 points, collected near the 
plant canopy) and banana cultivation areas (50 points, collected between rows). The points were georeferenced with the aid of Global Positioning System (GPS) to evaluate the spatial and temporal dependence (more samples were collected in areas with longer cultivation time) of the data using geostatistical techniques. Growing areas receive mineral and organic fertilizer every three months (Table 3).

Table 3. Mineral and organic fertilization in areas under banana and guava cultivation.

\begin{tabular}{ccccc}
\hline \multirow{2}{*}{ Use } & \multicolumn{2}{c}{ Mineral fertilization* } & \multicolumn{2}{c}{ Organic fetilization ** } \\
& Simple Superphosphato & $\mathrm{KCl}$ & Urea & Bovine + ovine manure \\
\hline Banana cultivation & 50 & 100 & 100 & $22 \mathrm{~L}$ \\
Guava cultivation & 100 & 100 & - & $18 \mathrm{~L}$ \\
\hline
\end{tabular}

$*^{*}$ plant $^{-1}$; plant $^{-1}$ quarterly $^{-1} \mathrm{KCL}=$ Potassium chloride.

The samples were air dried, broken into aggregates, and passed through a 2-mm mesh sieve. Subsequently, total organic carbon (TOC) levels were analyzed, and quantified by oxidation of wet organic matter with external heating, using a potassium dichromate solution following a method proposed by the Brazilian Agricultural Research Corporation (EMBRAPA, 1997). Chemical fractionation of humic substances (fractions: humic acid (C-HAF), fulvic acid (C-FAF), and humin (C-HUM)) was performed using methods proposed by the International Humic Substances Society (IHSS), as adapted by Benites et al. (2003).

Descriptive statistical analysis was performed using the STAT program with the geostatistical computer package GEOSTAT (VIEIRA et al., 1983). Initially, data were subjected to an exploratory analysis, to determine the mean, variance, standard deviation, coefficient of variation, extreme values (minima and maxima), and skewness and kurtosis coefficients. These two coefficients can be used to determine whether the data are normally distributed. All data were normally distributed, with the exception of C-HAF contents. Although normality is not a requirement for geostatistical analysis, C-HAF data were adjusted to best fit the semivariogram.

After the presence of spatial dependence was verified by adjusting the experimental semivariogram (VIEIRA, 2000), a theoretical model that best represents the data was developed, using variables such as range (a), nugget effect (Co), structural variance $(\mathrm{C} 1)$, and the sill $(\mathrm{C} 0+\mathrm{C} 1)$. The interrelationships between the variables in the semivariogram can be used to determine whether spatial variability is present in the analyzed attribute. If $\mathrm{C} 0=\mathrm{C} 0+\mathrm{C} 1$, the variation is random, and the range value indicates the strength of variability (the lower the range value, the greater the spatial variability). Thus, a geostatistical sampling scheme can be used to optimize sampling, so that a smaller number of samples can be collected in areas with little variability and larger numbers can be collected in areas with greater variability (ZANÃO JÚNIOR et al., 2010).

The semivariogram was estimated using the following equation:

$$
\gamma^{*}(h)=\frac{1}{2 N(h)} \sum_{i=1}^{N(h)}\left[Z\left(x_{i}\right)-Z\left(x_{i}+h\right)\right]^{2}
$$

in which

$\gamma^{*}=$ the semivariance among pairs of values separated by the distance $h$;

$h=$ distance among measured values;

$\mathrm{N}(h)=$ number of pairs of measured points, $\mathrm{Z}\left(\mathrm{x}_{\mathrm{i}}\right)$, $\mathrm{Z}\left(\mathrm{x}_{\mathrm{i}}+h\right)$; 
$\mathrm{Z}=$ attribute value; and,

$\mathrm{x}_{\mathrm{i}}=$ position of determined attribute

Subsequently, we performed model validation, using a tool called Jack Knifing (self-validation) for model adjustment (VIEIRA et al., 1983). This procedure compares the adjusted models and indicates the optimal number of neighboring pixels around the point being estimated. This tool showed that the adjusted model was adequate, and also determined the optimal vicinity for making estimates, that is, the number of points to be used for estimating values at the non-sampled points.

The spatial dependence index (IDE), proposed by Zimback (2001), was calculated to determine the degree of randomness. IDE values of $<25 \%$, $25-75 \%$, and $>75 \%$ represent weak, moderate, and strong spatial dependence, respectively.

After verification of the presence of spatial dependence through semivariogram adjustment, data interpolation was performed for the unsampled areas by kriging, using the parameters determined by the semivariogram (range, nugget effect, and structural variance), obtained from the best fit models, using the following equation:

$$
Z *\left(x_{0}\right)=\sum_{i=1}^{N} \lambda_{i} Z\left(x_{i}\right)
$$

In which

$Z^{*}=$ estimated values for the variable in the study;

$\mathrm{X}_{0}=$ point to be estimated;

$\mathrm{N}=$ number of neighbors used in the estimate;

$\lambda_{i}=$ weighted value associated with each measured value;

and, $\mathrm{Z}\left(\mathrm{x}_{\mathrm{i}}\right)=$ measured value.

To visualize the spatial distribution of the parameters, contour maps (isolines) were generated using the software ArcGIS v. 10, using kriging methods for most variables and the inverse square of the distance for TOC.

\section{Results and Discussion}

Data analysis using descriptive statistics (Table 4) allowed us to infer that the evaluated attributes showed high variability, suggesting high spatial variability. Normal distribution of the data was verified by analyzing the asymmetry coefficient and kurtosis, where values closer to zero for asymmetry and less than three for kurtosis indicated a normal distribution. The Shapiro-Wilk test for normality, at $5 \%$ probability, supported these results, because attributes with a normal distribution were those with smaller asymmetry coefficients.

Table 4. Descriptive statistics for TOC, C-HUM, C-HAF, C-FAF of soil samples collected in forested, guava cultivation, and banana cultivation areas.

\begin{tabular}{cllllllllc}
\hline Variable & Unit. & Mean & Min. & Max. & $\mathrm{S}$ & $\mathrm{S}^{2}$ & $\mathrm{CV}(\%)$ & Ass. & Kurt. \\
\hline TOC & $\mathrm{g} \mathrm{kg}^{-1}$ & 5.71 & 2.30 & 10.79 & 1.64 & 2.70 & 28.74 & 0.59 & 0.22 \\
C-HUM & $\mathrm{g} \mathrm{kg}^{-1}$ & 3.66 & 1.52 & 6.65 & 1.26 & 1.58 & 34.33 & 0.48 & -0.53 \\
C-HAF & $\mathrm{g} \mathrm{kg}^{-1}$ & 0.93 & 0.12 & 2.91 & 0.44 & 0.20 & 47.82 & 1.30 & 3.29 \\
C-FAF & $\mathrm{g} \mathrm{kg}^{-1}$ & 0.73 & 0.12 & 1.42 & 0.28 & 0.08 & 38.44 & 0.34 & -0.44 \\
\hline
\end{tabular}

$\mathrm{TOC}=$ total organic carbon, $\mathrm{C}-\mathrm{HUM}=$ carbon in the humin fraction, $\mathrm{C}-\mathrm{HAF}=$ carbon in the humic acid fraction, $\mathrm{C}-\mathrm{FAF}=\mathrm{carbon}$ in the fulvic acid fraction, Min. = minimum, Max. = maximum, $\mathrm{S}=$ standard deviation, $\mathrm{S}^{2}=$ variance, $\mathrm{CV}=$ coefficient of variation, Ass. = asymmetry; Kurt.= kurtosis. Normal distribution by Shapiro-Wilk's (w) test at 5\% probability. 
The spatial dependence of TOC, C-HUM, $\mathrm{C}-\mathrm{HAF}$, and C-FAF was verified by analysis of nugget effect parameters $\left(\mathrm{C}_{0}\right)$. The nugget effect represents the unexplained variability, which can be due to errors in sampling (sampling scale), in collection, in chemical and physical analysis, or the absence of spatial dependence. The sill $\left(\mathrm{C}_{0}+\right.$ $\mathrm{C}_{1}$ ) is reached when the variance remains constant. The range (a) represents the maximum correlation distance between samples, that is, based on the range, the samples are independent of each other, indicating that mean values, from classical statistics, should be used (Table 5). A pure nugget effect in the semivariogram denotes a random distribution in the study area. The TOC showed a pure nugget effect. C-FAF had a greater range, indicating that samples are correlated up to a distance of $50.36 \mathrm{~m}$; that is, beyond this distance, samples are independent of each other. Variables with the greatest range for spatial dependence tend to be more spatially homogeneous (GONTIJO et al., 2012).

Table 5. Semivariogram parameters for COT, C-HUM, C-HAF, and C-FAF of soil samples collected in forested, guava cultivation, and banana cultivation areas.

\begin{tabular}{clccccccc}
\hline Variable & Unity & Model & $\mathrm{C}_{0}$ & $\mathrm{C}_{1}$ & $\mathrm{C}_{0}+\mathrm{C}_{1}$ & $\mathrm{~A}$ & $\mathrm{R}^{2}$ & IDE \\
\hline TOC & $\mathrm{g} \mathrm{kg}^{-1}$ & Pure nugget effect & - & - & - & - & - & - \\
C-HUM & $\mathrm{g} \mathrm{kg}^{-1}$ & Gaussian & 0.0160 & 0.0070 & 0.0230 & 35.00 & 0.41 & 30 \\
C-HAF & $\mathrm{g} \mathrm{kg}^{-1}$ & Gaussian & 0.0266 & 0.0174 & 0.0440 & 29.00 & 0.46 & 40 \\
C-FAF & $\mathrm{g} \mathrm{kg}^{-1}$ & Gaussian & 0.0649 & 0.0267 & 0.0916 & 50.36 & 0.75 & 29 \\
\hline
\end{tabular}

$\mathrm{TOC}=$ organic total carbon, $\mathrm{C}-\mathrm{HUM}=$ carbon in the humin fraction, $\mathrm{C}-\mathrm{HAF}=$ carbon in the humic acid fraction, $\mathrm{C}-\mathrm{FAF}=$ carbon in the fulvic acid fraction, $\mathrm{C}_{0}=$ nugget effect, $\mathrm{C}_{1}=$ structural variance, $\mathrm{C}_{0}+\mathrm{C}_{1}=$ sill, $\mathrm{a}=$ range, $\mathrm{R}^{2}=$ determination coefficient, IDE= spatial dependence index $\left(\mathrm{C}_{1} / \mathrm{C}_{0}+\mathrm{C}_{1} * 100\right)$.

In the semivariograms of the TOC, C-HAF, C-FAF, and C-HUM fractions, shown in Figure 2, we observed that all showed a Gaussian distribution, with the exception of the TOC, that presents nugget effect.

Adjustment of the theoretical model to the experimental semivariogram is one of the most important aspects of the application of geostatistics, because according to Vieira (2000), the semivariogram model is the basis for all calculations used in geostatistics. Thus, adjustment of the semivariogram can result in differences in the spatial dependence of the values, according to which model is adopted.

The spatial distribution of the humic fractions (Figure 3) shows that more than $50 \%$ of the TOC in the different areas is comprised of the C-HUM fraction. Leite et al. (2003) found similar values for the C-HUM fraction, indicating that high C-HUM levels may be related to the greater resistance of this fraction and its association with soil minerals. In contrast, the FAF and HAF fractions show less stability, and can be polymerized, mineralized, or translocated into deeper layers, especially in sandy soils, thus reducing their residual contents in the soil (FONTANA et al., 2006).

Studies of carbon and nitrogen stocks in degraded semiarid areas of Brazil (areas at risk of desertification) in soils subjected to heavy grazing and areas with grazing exclusion, showed that the HUM fraction contained the highest $\mathrm{C}$ levels (ranging from $27-48 \%$ TOC), followed by the HAF and the FAF fractions. The authors attributed the low levels of $\mathrm{C}$ humification to the semi-arid conditions, which restrict microbial activity and hence the humification process (SOUZA et al., 2012). 
Figure 2. Semivariograms of variables: total organic carbon (TOC), carbon in the humin fraction (C-HUM), carbon in the humic acid fraction (C-HAF), and carbon in the fulvic acid fraction (C-FAF) collected in the forested, guava cultivation, and banana cultivation areas.
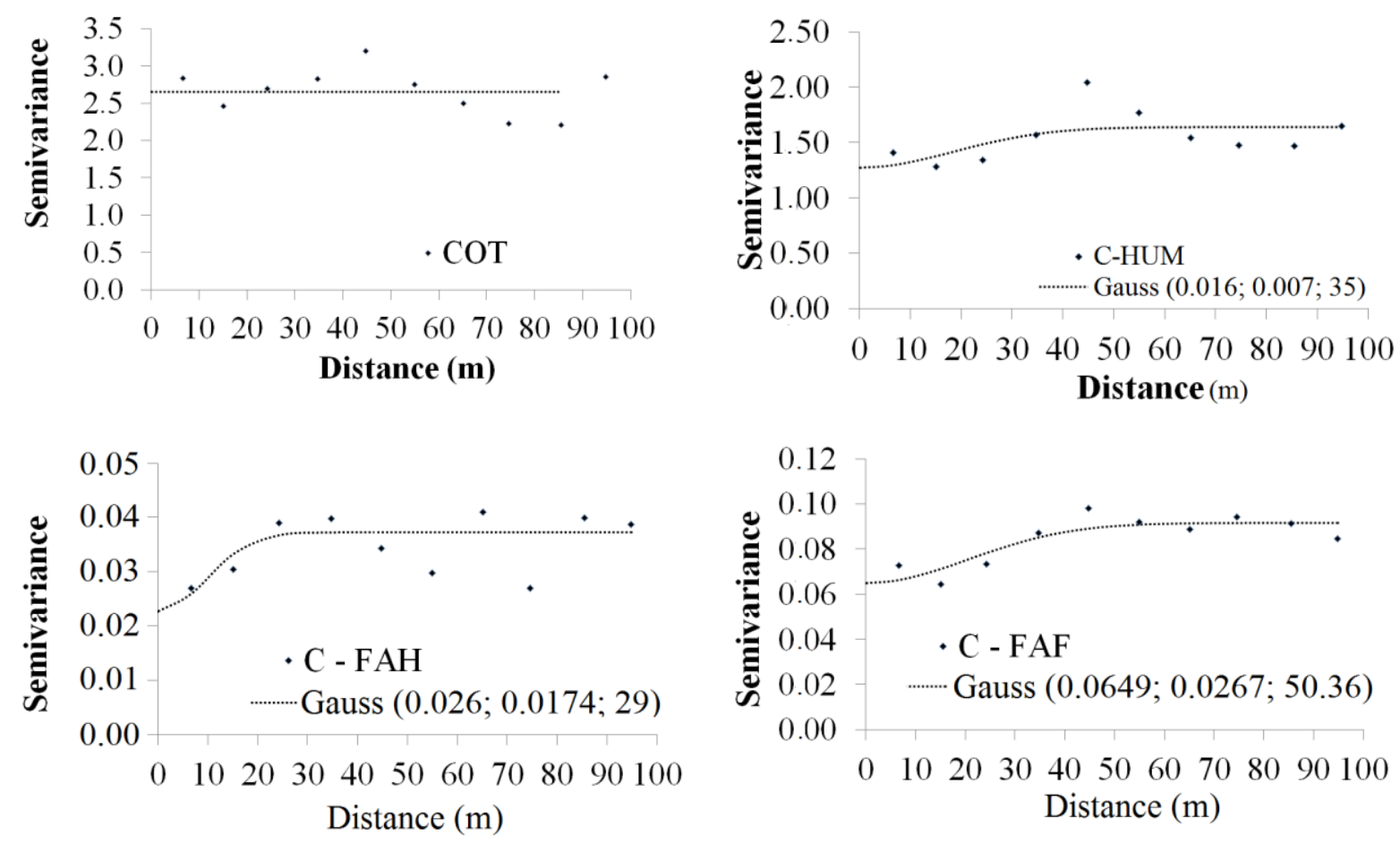

Figure 3 shows spatial distribution maps of the TOC, C-HUM, C-HAF, and C-FAF fractions in the study areas. The area under guava cultivation showed higher levels of C-HUM (2.7-5.5 $\left.\mathrm{g} \mathrm{kg}^{-1}\right)$ than areas under banana cultivation $\left(2.7-4.8 \mathrm{~g} \mathrm{~kg}^{-1}\right)$ or forested areas (2.0-4.1 $\left.\mathrm{g} \mathrm{kg}^{-1}\right)$ and lower levels of C-HAF (0.4-1.0 $\left.\mathrm{g} \mathrm{kg}^{-1}\right)$ and C-FAF (0.48-0.96 $\left.\mathrm{g} \mathrm{kg}^{-1}\right)$. Levels of $\mathrm{C}$-FAF were reduced in the central portion of the area under guava cultivation and increased approaching the guava-forested contacted areas, showing an edge effect, which was also be observed for C-HAF. The lower levels of C-HAF and C-FAF can be attributed to management because the soil is

bare in these areas, facilitating erosion. Althoug in forested areas (deciduous vegetation) and banana, the soil are covered by leaves and culture residues, respectively. Similar results were published by Assis et al. (2010) in a study on the fractions of organic matter and phosphorus in irrigated agro systems in a semiarid region of northeastern Brazil. The authors observed a reduction in C-FAF to a depth of 0.15 $\mathrm{m}$ in cultivated areas with respect to native forest and concluded that TOC stocks and the $\mathrm{C}$ content of humic substances are reduced by soil cultivation, regardless of the management system, resulting in reduced soil quality. 
Figure 3. Distribution maps of the spatial distribution variables, total organic carbon (TOC), carbon in the humin fraction (C-HUM), carbon in the humic acid fraction (C-HAF), and carbon in the fulvic acid fraction (C-FAF) collected in the forested, guava cultivation, and banana cultivation areas.
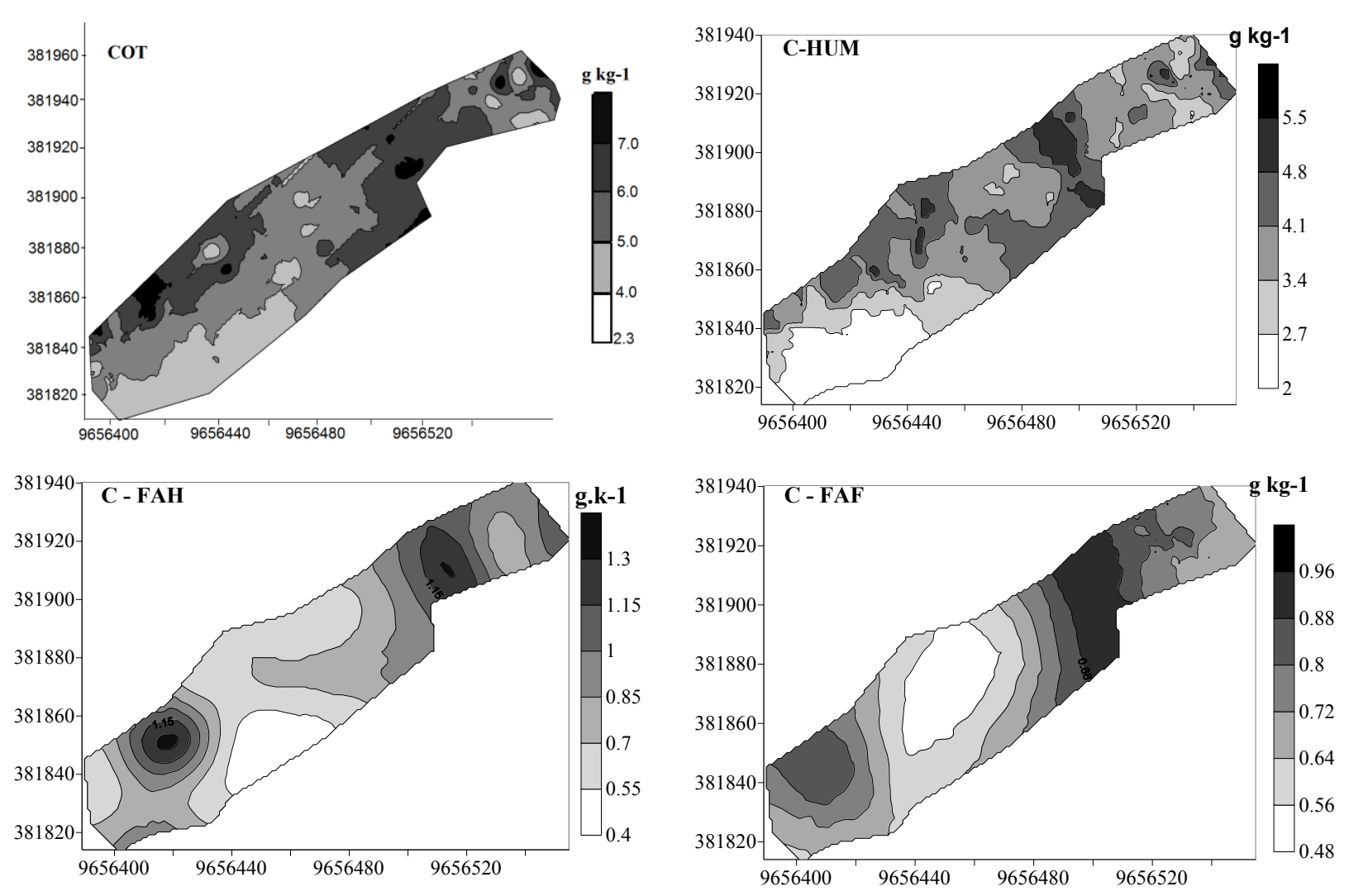

Maia et al. (2008) observed a reduction in humic fractions of $\mathrm{C}$ in intensive farming systems in relation to caatinga, demonstrating the effects of cultivation. In this study, reductions were only observed in the C-HAF and C-FAF fractions, because they have lower stability than the C- HUM fraction.

Forested areas and areas under banana cultivation (Figure 3) showed similar spatial distributions of the C-FAF fraction $\left(0.64-0.88 \mathrm{~g} \mathrm{~kg}^{-1}\right)$. Values for the $\mathrm{C}$-HAF fraction were similar in forested areas and areas under banana cultivation (0.55-1.3 and 0.7-1.3 $\mathrm{g} \mathrm{kg}^{-1}$, respectively). This pattern may be related to the lower soil disturbance and maintenance of crop residues (leaves and stalks) in the area under banana cultivation, and the absence of no soil disturbance in

the forested area, in addition to the litter contribution in the forested area (FONTANA et al., 2010).

Leite et al. (2003) observed increased polymerization of humic substances, with an increased ratio of C-HAF to C-FAF in a forested area. The authors concluded that in natural systems, increased organic matter helps to increase soil C-HAF.

The increased ratio of C-HAF to C-FAF observed in all management systems can be attributed to the higher mobility of C-FAF, which migrates to deeper layers. Similar results were found by Barreto et al. (2008) in an analysis of forested, pasture, and cocoa cultivation areas. Passos et al. (2007) observed increased C-FAH levels in the Cerradão area, concluding that the less mobile C-HAF and the 
slow decomposition of organic matter favored the humification process.

\section{Conclusions}

Banana cultivation and forested areas show similar distributions of the C-HAF and C-FAF humic fractions, due to a greater contribution of organic matter (leaves and stalks) in the banana cultivation area and to the absence of soil disturbance in the forested area.

Data interpolation (kriging) and mapping are useful tools to assess the distribution and spatial dependence of soil properties.

\section{Acknowledgements}

This research was supported by the CNPq, CAPES, UFC, and UFRRJ. The CNPq provided financial support (Proc. 471433/2009 8), and CAPES provided a scholarship through PROCAD (CAPES process PROCAD NF 064/2010).

\section{References}

ASSIS, C. P.; OLIVEIRA, T. S.; DANTAS, J. A. N.; MENDONÇA, E. S. Organic matter and phosphorus fractions in irrigated agroecosystems in a semi-arid region of Northeastern Brazil. Agriculture Ecosystems \& Environment, Amsterdam, v. 138, n. 1-2, p. 74-82, 2010.

BARRETO, A. C.; FREIRE, M. B. G. S.; NACIF, P. G. S.; ARAÚJO, Q. R.; FREIRE, F. J.; INACIO, E. S. B. Fracionamento químico e físico do carbono orgânico total em um solo de mata submetido a diferentes usos. Revista Brasileira de Ciência do Solo, Viçosa, MG, v. 32, n. 4, p. 1471-1478, 2008.

BENITES, V. M.; MADARI, B.; MACHADO, P. L. O. A. Extração e fracionamento quantitativo de substâncias húmicas do solo: um procedimento simplificado de baixo custo. Rio de Janeiro: Embrapa Solos, 2003. 7 p.

CUNHA, T. J. F.; BASSOI, L. H.; SIMÕES, M. L.; MARTIN NETO, L.; PETRERE, V. V. G.; RIBEIRO, P. R. A. Ácidos húmicos em solo fertirrigado no vale do São Francisco. Revista Brasileira de Ciência do Solo, Viçosa, MG, v. 33, n. 6, p. 1583-1592, 2009.
CUNHA, T. J. F.; CANELlAS, L. P.; SANTOS, G. A.; RIBEIRO, L. P. Fracionamento da matéria orgânica humificada de solos brasileiros. In: CANELAS, L. P.; SANTOS, G. A. (Ed.). Humosfera. Campos dos Goytacazes: do Autor, 2005. p. 54-80.

EBELING, A. G.; ANJOS, L. H. C.; PEREIRA, M. G.; PINHEIRO, E. F. M.; VALLADARES, G. S. Substâncias húmicas e relação com atributos edáficos. Bragantia, Campinas, v. 70, n. 1, p. 157-165, 2011.

EMPRESA BRASILEIRA DE PESQUISA AGROPECUÁRIA - EMBRAPA. Manual de métodos de análises de solo. 2. ed. Rio de Janeiro: Embrapa, 1997. $212 \mathrm{p}$.

FONTANA, A.; PEREIRA, M. G.; ANJOS, L. H. C.; BENITES, V. M. Quantificação e utilização das frações húmicas como característica diferencial em horizontes diagnósticos de solos Brasileiros. Revista Brasileira de Ciência do Solo, Viçosa, MG, v. 34, n. 4, p. 1241-1257, 2010.

FONTANA, A.; PEREIRA, M. G.; LOSS, A.; CUNHA, T. J. F.; SALTON, J. C. Atributos de fertilidade e frações húmicas de um Latossolo Vermelho no cerrado. Pesquisa Agropecuária Brasileira, Brasília, v. 41, n. 5, p. 47-853, 2006.

GONTIJO, I.; NICOLE, L. R.; PARTELLI, F. L.; BONOMO, R.; SANTOS, E. O. J. Variabilidade e correlação espacial de micronutrientes e matéria orgânica do solo com a produtividade da pimenta-do-reino. Revista Brasileira de Ciência do Solo, Viçosa, MG, v. 36, n. 4, p. 1093-1102, 2012.

LEITE, L. F. C.; MENDONÇA, E. S.; NEVES, J. C. L.; MACHADO, P. L. O. A.; GALVÃO, J. C. C. Estoques totais de $\mathrm{C}$ orgânico e seus compartimentos em Argissolo sob floresta e sob milho cultivado com adubação mineral e orgânica. Revista Brasileira de Ciência do Solo, Viçosa, MG, v. 27, n. 5, p. 821-832, 2003.

LIMA, J. S. S.; OLIVEIRA, R. B.; ROCHA, W.; OLIVEIRA, P. C.; QUARTEZANI, W. Z. Análise espacial de atributos químicos do solo e da produção da cultura pimenta-do-reino (Piper nigrum, L.). IDESIA, Arica, v. 28, n. 2, p. 31-39, 2010.

LOSS, A.; PEREIRA, M. G.; BRITO, R. J. Distribuição das substâncias húmicas em solos de tabuleiros sob diferentes coberturas vegetais. Revista Universidade Rural: Série Ciências da Vida: EDUR, Seropédica, v. 26, n. 2, p. 68-77, 2006.

LOSS, A.; PEREIRA, M. G.; SCHULTZ, N.; ANJOS, L. H. C.; SILVA, E. M. R. Quantificação do carbono das substâncias húmicas em diferentes sistemas de uso do 
solo e épocas de Avaliação. Bragantia, Campinas, v. 69, n. 4, p. 913-922, 2010.

MADARI, B. E.; CUNHA, T. J. F.; NOVOTNY, E. H.; MILORI, D. M. B. P.; MARTIN NETO, L.; BENITES, V. M.; COELHO, M. R.; SANTOS, G. A. Matéria orgânica dos solos antrópicos da Amazônia (Terra Preta de Índio): suas características e papel na sustentabilidade da fertilidade do solo. In: TEIXEIRA, W. G.; KERN, D. C.; MADARI, B. E.; LIMA, H. N.; WOODS, W. (Ed.). As terras pretas de Índio da Amazônia: sua caracterização e uso deste conhecimento para criação de novas áreas. Manaus: Embrapa Amazônia Ocidental, 2009. p. 172188.

MAIA, S. M. F.; XAVIER, F. A. S.; OLIVEIRA, T. S.; MENDONÇA, E. S.; ARAÚJO FILHO, J. A. Frações de nitrogênio em Luvissolo sob sistemas agroflorestais e convencional no semiárido cearense. Revista Brasileira de Ciência do Solo, Viçosa, MG, v. 32, n. 1, p. 381-392, 2008.

MARTINS, E. L.; CORINGA, J. E. S.; WEBER, O. L. S. Carbono orgânico nas frações granulométricas e substâncias húmicas de um Latossolo Vermelho Amarelo distrófico - LVAd sob diferentes agrossistemas. Acta Amazônica, Manaus, v. 39, n. 3, p. 655-660, 2009.

PASSOS, R. R.; RUIZ, H. A.; MENDONÇA, E. S.; CANTARUTTI, R. B.; SOUZA, A. P. Substâncias húmicas, atividade microbiana e carbono orgânico lábil em agregados de um latossolo vermelho distrófico sob duas coberturas vegetais. Revista Brasileira de Ciência do Solo, Viçosa, MG, v. 31, n. 5, p. 1119-1129, 2007.

PESSOA, P. M. A.; DUDA, G. P.; BARROS, R. B.; FREIRE, M. B. G. S.; NASCIMENTO, C. W. A.; CORREA, M. M. Frações de carbono orgânico de um Latossolo Húmico sob diferentes usos no agreste brasileiro. Revista Brasileira de Ciência do Solo, Viçosa, MG, v. 36, n. 1, p. 97-104, 2012.
SOUZA, F. P.; FERREIRA, T. O.; ROMERO, R. E.; OLIVEIRA, J. G. B. Carbon and nitrogen in degraded Brazilian semi-arid soils undergoing desertification. Agriculture Ecosystems \& Environment, Amsterdam, v. 148, n. 1, p. 11-21, 2012.

SOUZA, Z. M. de; MARQUES JÚNIOR, J.; PEREIRA, G. T.; MONTANARI, R.; CAMPOS, M. C. C. Soil sampling viewing the determination of chemical and physical attributes in areas with different pedoforms. Cientifica, Jaboticabal, v. 34, n. 2, p. 249-256, 2006.

SUDEC/Departamento Nacional de Obras contra as Secas. Levantamento de reconhecimento dos solos de parte do Vale Acaraú. Fortaleza: Ed. Fortaleza, SUDEC, 1974. $183 \mathrm{p}$.

VALLADARES, G. S.; BATISTELLA, M.; PEREIRA, M. G. Alterações ocorridas pelo manejo em Latossolo, Rondônia, Amazônia Brasileira. Bragantia, Campinas, v. 70, n. 3, p. 631-637, 2011.

VIEIRA, S. R. Geoestatística em estudos de variabilidade espacial do solo. In: NOVAIS, R. F.; ALVARES, V. H.; SCHAEFER, C. E. G. R. (Ed.). Tópicos em ciência do solo. Viçosa, MG: Sociedade Brasileira de Ciência do Solo, 2000. p. 1-54.

VIEIRA, S. R.; HATFIELD, J. L.; NIELSEN, D. R.; BIGGAR, J. M. Geostatistical theory and application to variability of some a agronomical properties. Hilgardia, Davis, v. 51, n. 1, p. 1-75, 1983.

ZANÃO JÚNIOR, L. A.; LANA, R. M. Q.; GUIMARÃES, E. C.; PEREIRA, J. M. A. Variabilidade espacial dos teores de macronutrientes em Latossolos sob sistema de plantio direto. Revista Brasileira de Ciência do Solo, Viçosa, MG, v. 34, n. 2, p. 389-400, 2010.

ZIMBACK, C. R. L. Análise espacial de atributos químicos de solos para fins de mapeamento da fertilidade. 2001. Tese (Livre Docência em Levantamento do Solo e Fotopedologia) - Faculdade de Ciências Agronômicas, Universidade Estadual Paulista, Botucatu. 
